\title{
PHYTOSEIID MITES (ACARI: PHYTOSEIIDAE) OF KENYA,WITH DESCRIPTIONS OF FIVE NEW SPECIES AND COMPLEMENTARY DESCRIPTIONS OF EIGHT SPECIES
}

\author{
G. J. de Moraes ${ }^{1}$, J. A. McMurtry ${ }^{2}$, H. van den Berg ${ }^{3}$ and J. S. Yaninek ${ }^{4}$ \\ 1. CNPDA/EMBRAPA, 13820 Jaguariuna, SP, Brazil; 2. Department of Entomology, University of California, River- \\ side, 92521 USA; 3. C.A.B. International, Kenya Station; 4. Africa-wide Biological Control Program, Intemational In- \\ stitute of Tropical Agriculture, Cotonou, Benin.
}

\begin{abstract}
New records of phytoseiid mites from Kenya are given. Five new species are described: Amblyseius msabahaensis, Euseius minutisetus, Phytoseius kisumuensis, Phytoseius neohongkongensis, Phytoseius neomontanus. The descriptions of eight species are complemented.
\end{abstract}

\section{INTRODUCTION}

Considerable attention has been given in recent years to the knowledge of the predaceous phytoseiid mites in Africa, in relation to an on going multi-national effort for the biological control of the cassava green mite, Mononychellus tanajoa (Bondar), in Africa (Yaninek \& Herren,1988). This paper refers to phytoseiids collected on plants in Kenya in sporadic surveys conducted from 1984 to 1986. Prior to this paper, Moutia (1958), Swirski \& Ragusa (1978) and Moraes \& McMurtry (1988) reported on phytoseiids from this country.

All measurements are given in micrometers. For all species, the width of the dorsal shield refers to the widest level of the proscutum. The setal nomenclature follows that of Rowell et al. (1978) and Chant \& Hansell (1971) for dorsal and ventral surfaces, respectively. The classification system adopted is that of Chant (1965) as modified by Chant et al. (1978), McMurtry (1983) and Chant \& Yoshida Shaul (1986). The distance between sternal setae ST1 and ST3 refers to the distance of ST1 to its projection on an imaginary line linking ST3 setae of both sides. Unless otherwise specified, the collector was $H$. van den Berg, the host plant was cassava (Manihot esculenta Crantz) and previous redords mentioned under each species are based on Moraes et al. (1986).

Genus Amblyseius Berlese

Amblyseius Berlese, 1914: 143; Chant, 1965: 371.
Amblyseius adathodae Muma

Amblyseius adathodae Muma, 1967: 268.

SPECIMENS EXAMINED: Karachi, Pakistan, Adathoda vasica, 4-IX-1964, M.A. Ghani (holotype); Kilifi, Asystasia gangetica, X- 1984.

PREVIOUS RECORDS: India and Pakistan.

REMARKS: The specimens collected agree well with our measurements of the holotype. The ranges of 2 females collected (in parentheses) and the corresponding measurements of the female holotype are: dorsal shield length (360-374) 377 , width (240-264) $258, \mathrm{j} 1$ (2631) $36, \mathrm{j} 3(50-53) 52, \mathrm{j} 4$ and j5 (5) 4, j6 (5) $5, \mathrm{~J} 2$ (10) $6, \mathrm{~J} 5$ (10-12) $10, \mathrm{z2}$ (7) 7, z4 (7) 8, z5 (5) 5, Z1 (10) 8, Z4 (127-

132) $142, Z 5$ (283-305) 312, s4 (108-110) 133, S2 and S4 (12) 11, S5 (10) 10, r3 (12-14) 14, R1 (10) 10, SgeI (3841) 46, SgeII (34-38) 37, SgeIII (48-50) 58, StiIII (43-46) 47, SgeIV (122-132) 152, StiIV (86-91) 112, StIV (79-82) 74, ST1-ST3 (62- 65) 66, ST2-ST2 (67-72) 72, G-G (70) 74 , ventrianal shield length (108) 120 , width at $Z V 2$ level (62) 66, width at anus level (77) 84, cervix of spermatheca (36-41) (not measured in holotype), fixed digit (31) 30, movable digit (34) 32 . The specimens collected have ca. 10 and 3 teeth on the fixed and movable digits, respectively.

\section{Amblyseius herbicolus (Chant)}

Typhlodromus (Amblyseius) herbicolus Chant, 1959: 84 .

Amblyseius herbicolus, Daneshvar \& Denmark, 1982: 5; McMurtry \& Moraes, 1984: 34. 
Amblyseius deleoni Muma \& Denmark, in Muma et al., 1970: 68; Schicha, 1981: 107 (synonymy according to Daneshvar \& Denmark, 1982).

SPECIMENS EXAMINED:Tsavo National Park, West Kilaguni, unidentified tree, II-1985, J.A. McMurtry.

PREVIOUS RECORDS: Angola, Guatemala, Iran, New Caledonia, Papua New Guinea, Puerto Rico, West Indies, South Africa and USA; Australia, Brazil, China, Colombia, Indonesia, Japan, Madagascar, Taiwan and Thailand (as $A$. deleoni).

\section{Amblyseius aff. marginatus Wainstein}

Amblyseius marginatus Wainstein, 1961: 158; Livshitz \& Kuznetsov, 1972: 25; Wainstein \& Shcherbak, 1972: 38.

Amblyseius polyporus Wainstein, 1962a: 143 (synonymy, according to Wainstein, 1975).

Typhlodromus subtilisetosus Beglyarov, 1962: 199

(synonymy, according to Wainstein, 1975).

SPECIMENS COLLECTED: Kakamega, Triumfetta sp., IX-1985.

PREVIOUS RECORDS: Algeria and USSR.

REMARKS: The only female specimen collected has generally shorter dorsal shield setae, especially $1, j 3$, $\mathrm{z} 2, \mathrm{z4}, \mathrm{s} 4, \mathrm{Z4}$ and $\mathrm{Z5}$. Further collections may prove that it belongs to a new species. The measurements of this specimen are: dorsal shield length 336 , width $187, \mathrm{j} 117$, j3 26, j4 14, j5 and j6 12, J2 14, J5 10, z2 and z4 24, z5 12, $\mathrm{Z1} \mathrm{17,} \mathrm{Z4} \mathrm{50,} \mathrm{Z5} \mathrm{62,} \mathrm{s4} \mathrm{36,} \mathrm{S2} \mathrm{34,} \mathrm{S4} \mathrm{24,} \mathrm{S5} \mathrm{19,} \mathrm{r3} \mathrm{and} \mathrm{R1}$ 22, StIV 74, ST1-ST3 58, ST2-ST2 65, G-G 65, ventrianal shield length 110, width at ZV2 level 108, width at anus level 91, cervix of spermatheca 24 (cup-shaped distal portion 14 long, and constrict proximal portion $10 \mathrm{long}$ ), movable and fixed digits 31 each, with 1 and 3 teeth, respectively.

Amblyseius msabahaensis Moraes \& McMurtry, n. sp.

(Figs. 1-8)

DIAGNOSIS - This species is similar to Amblyseius makuwa Ehara but has the margins of the dorsal shield striated and $\mathrm{z} 2, \mathrm{Z4}, \mathrm{s} 4, \mathrm{~S} 2$ and $\mathrm{r} 3$ longer. Amblyseius dimidiatus DeLeon differs from $A$. msabahaensis by having shorter $\mathrm{s}$ and $\mathrm{Z4}$, and $\mathrm{z} 2$ about as long as z4. Amblyseius reptans Blommers is also similar to this new species, but has shorter $\mathrm{j} 3, \mathrm{~s} 4, \mathrm{r} 3$, SgeIV and StilV. In addition, the male of $A$. reptans has only 3 pairs of preanal setae.

FEMALE - (Figs. 1-5) (6 specimens measured).

Dorsum - Dorsal shield with a few striae on the margins, 347 (343-353) long and 208 (199-216) wide. Setae j1 22 (22-24), j3 27 (24-31), j4 and j5 9 (6-10), j6 8
(6-10), J2 10 (8-12), J5 9 (7-10), z2 20 (19-22), z4 13 (1214), z5 8 (7-8), Z1 12 (10-12), Z4 56 (50-58), Z5 70 (6572), s4 41 (38-46), S2 22 (22-26), S4 13 (12-15), S5 11 (1012), r3 28 (24-31), R1 17 (14- 17). All setae smooth, except for Z4 and Z5 which are very lightly barbed.

Peritreme - Extending forward to level of $\mathrm{j} 1$.

Venter - All shields well distinguishable. Sternal shield with 3 pairs of setae. Distances between sternal setae ST1-ST3 63 (60-67), ST2-ST2 65 (65-67), and genital setae G-G 63 (60-65). Ventrianal shield striated, 124 (120-130) long, 89 (88-91) wide at ZV2 level and 85 (8486) wide at anus level; with 3 pairs of preanal setae and a pair of preanal pores ca. in line with JV2.

Chelicera - Movable digit 34 long, with 1 tooth; fixed digit 31 (29-31) long, with 5 teeth.

Spermatheca - Cervix trumpet-like, 52 (48-55) long, including the flared distal portion which is $8(7-10)$ long.

Legs - With setiform macrosetae only on leg IV: Sge 49 (48-50), Sti 29 (26-31), St 52 (48-55). Chaetotaxy of GeII 2, 2/1, 2/0, 1; GeIII 1, 2/1, 2/0, 1.

MALE - (Figs. 6-8) (2 specimens measured).

Dorsum - Dorsal shield with a few striae on the margins, 264-286 long and 180-187 wide. Setae j1 18-19, j3 22, j4, j5, j6 and J2 10, J5 7, z2 14-17, z4 14, z5 8-10, Z1 12, Z4 38-41, Z5 48-50, s4 26-29, S2 14-17, S4 12-13, S5 $10-11$, r3 17, R1 12-14. All setae smooth, except for Z4 and $\mathrm{Z} 5$ which are barbed.

Peritreme - Extending forward to $\mathrm{j} 1$.

Venter - Ventrianal shield sub-triangular, with 6 pairs of preanal setae and a pair of pores; $108-120$ long and 134-142 wide at anterior corners.

Spermatodactyl - Shaft 31 long.

Legs - With setiform macrosetae only on leg IV: Sge 34, Sti 19, St 41.

LOCALITY AND TYPE MATERLAL Holotype female (EMBRAPA), Msabaha, Triumfetta rhomboidea, 10-IX-1985, H. van den Berg; 6 paratype females, 1 allotype male and 2 paratype males (EMBRAPA), Msabaha, Indigofera hirsuta, Pseudovigna argentea, Tephrosia villosa, Teramnus labiatus, 10-IX1985, H. van den Berg.

$$
\text { Amblyseius olombo Pritchard \& Baker }
$$

(Fig. 9)

\footnotetext{
Amblyseius (Amblyseius) olombo Pritchard \& Baker, 1962: 252.

SPECIMENS EXAMINED: Stanleyville (now Kisangani), Zaire, Vilex congolensis, 18-V-1955, E.W. Baker (paratype); Saiwa, Momordica foetida, IX-1986.

PREVIOUS RECORDS: Zaire.

REMARKS: The specimens collected are close to the paratype examined. The average measuremcnts of the 4
} 


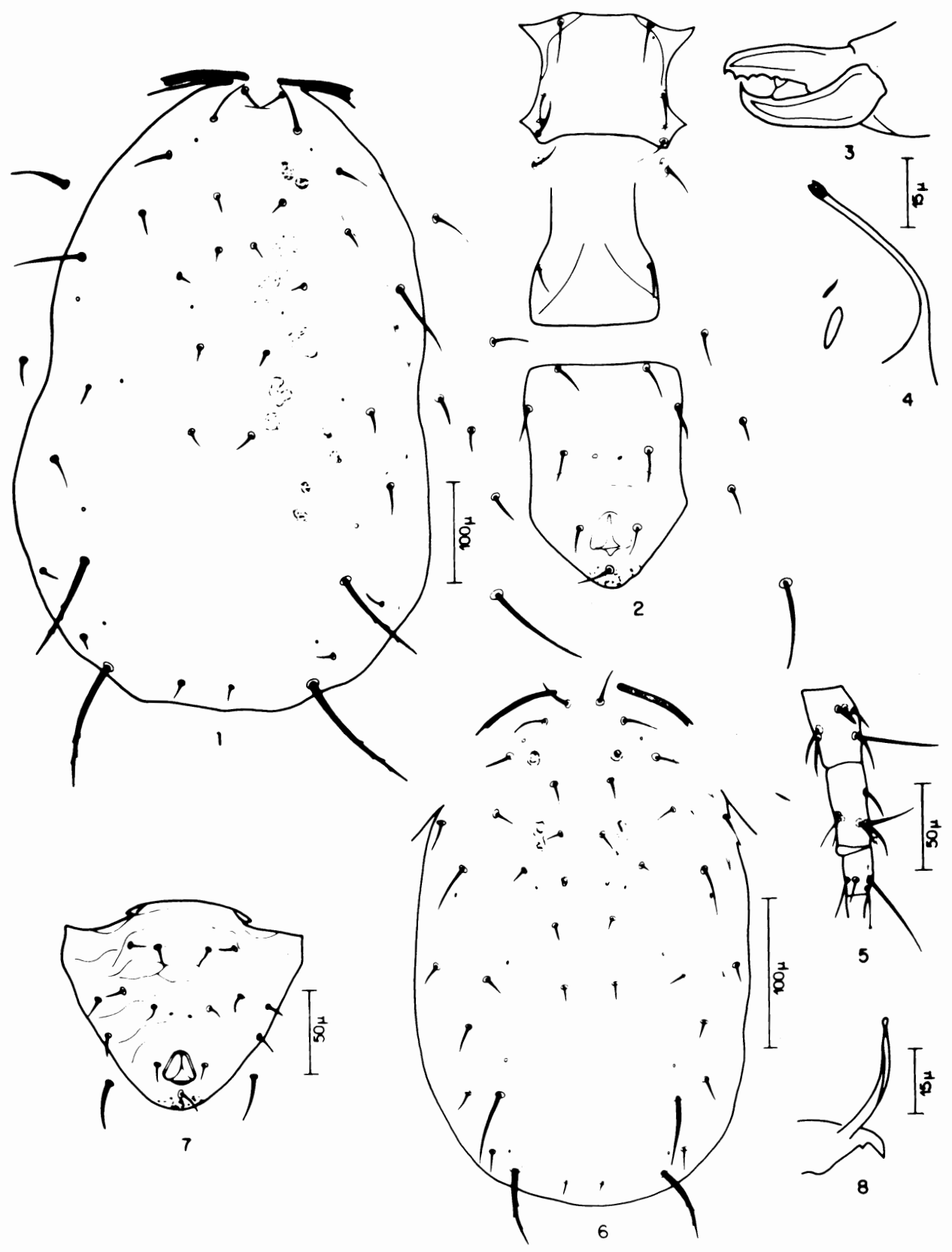

Figs. 1-8. Amblyseius msabahaensis n. sp.. FEMALE: 1 . dorsal shield; 2 . ventral surface; 3 . chelicera; 4 . spermatheca; 5. genu, tibia and basitarsus of leg IV. MALE: 6. dorsal shield; 7. ventrianal shield; 8 . spermatodactyl.

females collected followed by the respective ranges and the measurements of the female paratype are: dorsal shield length 370 (348-379) 283, width 234 (230-238) 180, j1 33 (31-34) 33, j3 44 (43-46) $42, \mathrm{j} 4$ and j5 15 (14-17) 16, j6 20 (17-22) 20, J2 22 (22) 21, J5 10 (10) not measured, z2 22 (22-24) 18, z4 40 (36-43) 38, z5 14 (14) 14, Z1 22 (21-24) 17, Z4 52 (50-53) 45, Z5 79 (77-82) 71, s4 53 (53-55) 52, S2 48 (46-50) 47, S4 21 (19-22) 29, S5 12 (10-12) 8, r3 24
(22-26) 22, R1 17 (14-18) 13, SgeI 27 (26-29) 23, Sgell 28 (26-29) 27, SgeIII 35 (34-36) 34, SgeIV 58 (55-60) 53, StiIV 36 (36-38) 31, StIV 84 (82-84) 65, ST1-ST3 72 (70-72) 63, ST2-ST2 72 (70-72) 69, G-G 83 (79-84) not measured, ventrianal shield length 118 (113-122) 123, width at ZV2 level 64 (58-67) 66, width at anus level 72 (67-74) 63, fixed and movable digits ca. 38 each (not measured in paratype), cervix of spermatheca 24 , (bulbous 


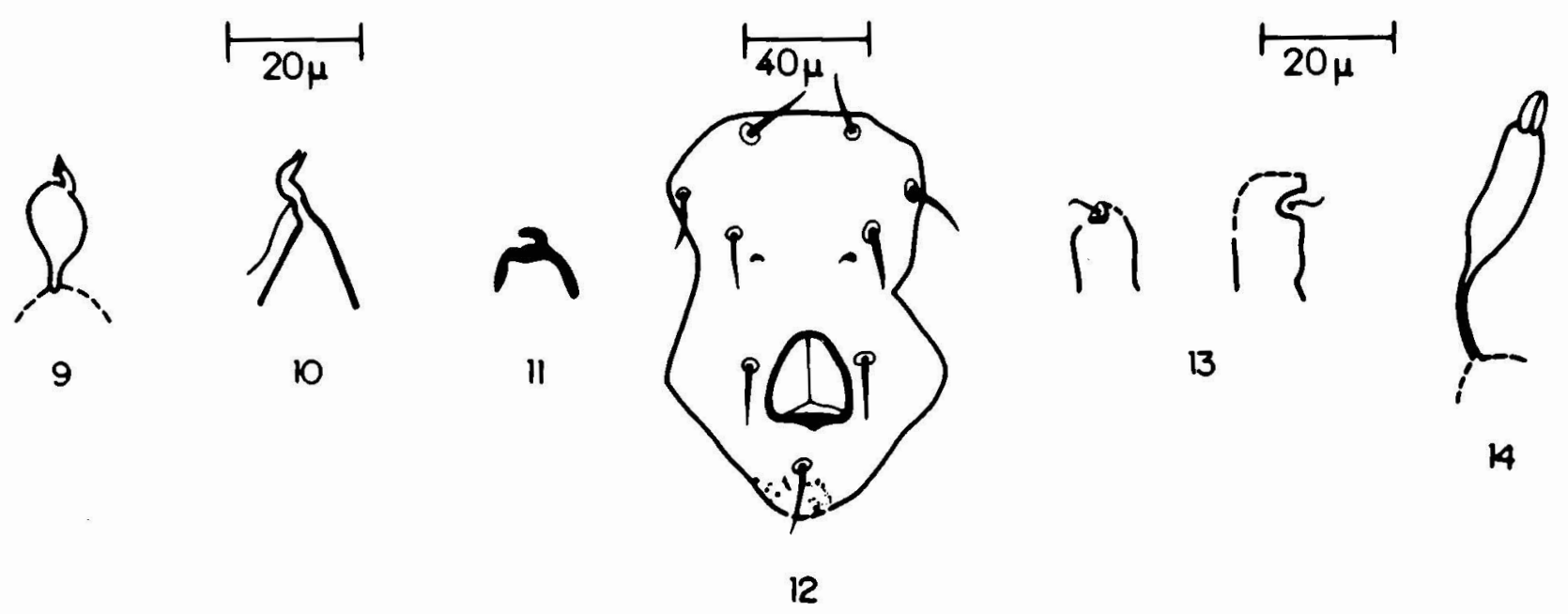

Figs.9-14. SPERMATHECAE: 9. Amblyseius olombo Pritchard \& Baker (paratype from Stanleyville, now Kisangani, Zaire); 10. Amblyseius rykei Pritchard \& Baker (specimen collected in Katumani, Kenya); 11. Amblyseius shi Pritchard \& Baker (paratype from Mulunga, Zaire); 13. Euseius dossei (Pritchard \& Baker) (paratype from Leopoldville, now Kinshasa, Zaire); 14. Euseius hima (Pritchard \& Baker) (holotype). VENTRIANAL SHIELD: 12. A. shi (holotype).

proximal portion 17 (14-19) 14 , constrict intermediate portion 2 (2) 2, conic distal portion 5 (2-7) not measured). In some specimens, the conic portion of the spermatheca is not distinguishable.

\section{Amblyseius rykei Pritchard \& Baker}

(Fig. 10)

Amblyseius (Amblyseius) rykei Pritchard \& Baker, 1962: 249.

Amblyseius rykei, Schicha, 1983: 108.

Typhlodromips rykei, Matthysse \& Denmark, 1981: 346.

SPECIMENS EXAMINED: Katumani, IX-1985, VI-, VII- and VIII-1988, C.W. Kariuki, H. van den Berg. PREVIOUS RECORDS: India, Kenya, Nigeria and Zaire.

REMARKS: The specimens collected are somewhat larger than the paratype described by Schicha (1983), which we also have seen. Consequently some of the setae of the specimens collected are longer. Thus $\mathrm{z2}$, Z4, s4 and SgeIV are 14, 74, 82 and 70 in the collected specimens, and 8, 64, 66 and 60 in the paratype, respectively. The spermatheca of the specimens collected (fig. 10) has a constricted proximal portion (ca. 2 long) and a conic distal portion (ca. 12 long).

\section{Amblyseius saltus (Denmark \& Matthysse)}

Euseius saltus Denmark \& Matthysse, in Matthysse
\& Denmark, 1981: 348.

SPECIMENS EXAMINED: Moor Plantation, Ibadan, Nigeria, Solanum incanum, 12-IV-1974, J.G. Matthysse (holotype); Msabaha, IX-1985; Kilifi, IX-1985; Margarini, Melhania velutina, IX-1985.

PREVIOUS RECORDS: Nigeria.

REMARKS: Measurements of the specimens collected are close to our measurements of the holotype, which are somewhat different from the measurements given in the original description of the species. All shields are lightly sclerotized. All setae have very sharp tips; this often makes them difficult to measure. The ranges of the measurements of 2 females collected (in parentheses) followed by our measurements of the female holotype are: dorsal shield length (360) 330 , width (235) 228, j1 (24) 24 , j3 (24-26) 22, j4 (5-6) 7, j5 (5) 8, j6 (10-12) 8, J2 (14) 12, J5 (10) 8, z2 (17-19) 16, z4 (15-19) 16, z5 (7-10) 8, Z1 $(12-17) 14, \mathrm{ZA}(17-19) 17, \mathrm{ZS}$ (24) $22, \mathrm{~s} 4$ (19) $17, \mathrm{~S} 2$ (17-19) 18, S4, S5 and r3 (17) 17, R 1 (17-19) 17, Sgel (not distinguishable) 24, SgeII (14) 16, SgeIII (24-26) 24, Stilll (34-36) 30, SgelV (26-34) 30, StilV (55-58) 44, StIV (55-58) 48, ST1-ST3 (55-60) 60, ST2-ST2 (65-67)62, G-G $(60-65) 62$, ventrianal shield length (96-101) 102 , width at ZV2 level (53-60) 52, width at anus level (70-79) 68, fixed $\operatorname{digit}(31) 26$, movable digit (31) 30 . Cervix of spermatheca (24) 26 (bulbous proximal portion (12) 10 , constrict portion (12) 16). In one of the specimens collected there is a distal conic portion ca. 7 long. The fixed digit has ca. 8 teeth. 
Amblyseius shi Pritchard \& Baker

(Figs. 11, 12)

Amblyseius (Amblyseius) shi Pritchard \& Baker, 1962: 252.

SPECIMENS EXAMINED: Stanleyville (now Kisangani), Zaire, Aframomum sp., 20-IV-1955, E.W. Baker (holotype); Kakamega, Triumfetta sp., Ipomoea sp., IX- and XI-1985.

PREVIOUS RECORDS: Nigeria and Zaire.

REMARKS: The specimens collected have some setae longer than the holotype. The average measurements of the 3 females collected, followed by the respective ranges and the measurements of the female holotype are: dorsal shield length 346 (329-355) 330, width 224 (216-230) 204, j1 17 (17) 16, j3 21 (19-22) 19, j4 10 (9-12) $11, \mathrm{j} 59(9-10) 10$, j6 11 (10-12) 11, J2 14 (12-14) 12, J5 9 (9-10) 8, z2 12 (12-13) 13, z4 12 (12-13) 13, z5 10 (10) 9, Z1 14 (12-14) 14, Z4 39 (36-41) 31, Z5 79 (77-82) 67, s4 29 (26- 31) 18, S2 10 (10-12) 12, S4 10 (10) 11, S5 9 (710) 9 , r3 17 (17) 14, R1 12 (12) 10, SgeI 31 (30-31) 27, SgeII 28 (26-29) 24, SgeIII $32(30-34) 28$, StiIII 26 (2426) 24 , SgeIV $53(50-53) 41$, StiIV 41 (41) 34 , StIV 65 (6267) 46, ST1-ST3 55 (55) 53, ST2-ST2 62 (62) 63, G-G 67 (67-70) 66, ventrianal shield length 115 (113- 115) 110), width at ZV2 level 94 (91-98) 78, width at anus level 86 (84-91) 82, fixed and movable digits 26 (26) (not measured in the holotype), cervix of spermatheca with a cup-shaped distal portion ( 5 long) and a constrict proximal portion (ca. 2 long). The ventrianal shield of the holotype has a much more pronounced constriction behind the preanal pores (fig. 12) than shown in the original description.

\section{Amblyseius tamatavensis Blommers}

Amblyseius (Amblyseius) tamatavensis Blommers, 1974: 144.

Amblyseius tamatavensis, Schicha, 1981: 40.

SPECIMEN EXAMINED: Machakos/Katumani, VI-1988, C.W. Kariuki.

PREVIOUS RECORDS: Australia, Indonesia, Madagascar, Papua New Guinea, New Hebrides, South Africa and Western Samoa.

\section{Amblyseius teke Pritchard \& Baker}

Amblyseius (Amblyseius) teke Pritchard \& Baker, 1962: 239; Van der Merwe, 1968: 141.

SPECIMENS EXAMINED: Kilifi, Manihot esculenta, Sida rhombifolia, IX-1985; Siaya, IX-1985; Nkubu, Meru, Pseudatrichia hookeri, X-1985; Msabaha, IX-1985.

PREVIOUS RECORDS: Kenya, Mozambique, South Africa and Zaire.
Genus Euseius Wainstein

\author{
Amblyseius (Amblyseius) section Euseius \\ Wainstein, 1962b: 15. \\ Euseius, DeLeon, 1966: 86; McMurtry, 1983: 257. \\ Euseius africanus (Evans)
}

Typhlodromus africanus Evans, 1954: 524.

Euseius africanus, Moraes \& McMurtry, 1988: 15.

SPECIMENS EXAMINED: Msabaha, IX-1985, Markhamia sp.; East Kilaguni, Tsavo National Park, Citrus sp., II-1985, J.A. McMurtry; West Kilaguni, Tsavo National Park, unknown tree, II- 1985, J.A. McMurtry.

PREVIOUS RECORDS: Kenya and Tanzania.

\section{Euseius albizziae (Swirski \& Ragusa)}

Amblyseius albizziae Swirski \& Ragusa, 1978: 398. SPECIMENS EXAMINED: Rusinga Island, Ricinus communis and unknown tree, IX-1986, G.J. Moraes.

PREVIOUS RECORDS: Kenya.

REMARKS:The specimens collected have setae z2 (34-36), z4 (50-53), Z5 (67), s4 (72-79), SgeIV (65) and StIV (70-72) longer than mentioned in the original description (22-23, 40-45, 56-60, 58-61, 51-53 and 61, respectively). The cone-shaped portion of the spermatheca is not distinctly sclerotized in some specimens.

\section{Euseius dossei (Pritchard \& Baker)}

(Fig. 13)

Amblyseius (Amblyseius) dossei Pritchard \& Baker, 1962: 286.

SPECIMENS EXAMINED: Leopoldville (now Kinshasa), Zaire, lemon leaf, 14-IV-1955, E.W. Baker (paratype); Kisiani, $15 \mathrm{~km}$ west of Kisumu, Psidium. guajava, I-1985, G.J. Moraes \& J.A. McMurtry.

PREVIOUS RECORDS: Nigeria and Zaire.

REMARKS: The ranges of the measurements of 2 females collected (in parentheses) and our corresponding measurements of the female paratype are: dorsal shield length (324-326) 298, width (240) 219, j1 (26-34) 31, j3 (29-31) 31, j4 and j5 (12) 9, j6 (17) 11, J2 (17-19) $11, \mathrm{~J} 5$ (5-7) 5, z2 (24) 25, z4 (31) 34, z5 (12) 9, Z1 (17-19) 13 , Z4 (19) 11, Z5 (67) 75, s4 (53) 55, S2 (26-29) 25, S4 (29) 27 , S5 (29-31) 20, r3 (17-19) 16, R1 (12) 11, SgeI (2629) 28 , SgeII (29) 28 , SgeIII (36-38) 36 , StilII (24-26) 22 , SgeIV (48-50) 50, StiIV (29-31) 31, StIV (53) 64, ST1ST3 (55) 48, ST2-ST2 (72) 59, G-G (77-84) 77, ventrianal shield length (98-103) 99, width at ZV2 level (50-53) 45, width at anus level (79) 69, cervix of spermatheca (13) 11. The peritreme extends forward up to between $j 3$ and z2. Macrosetae of all legs are knobbed. 


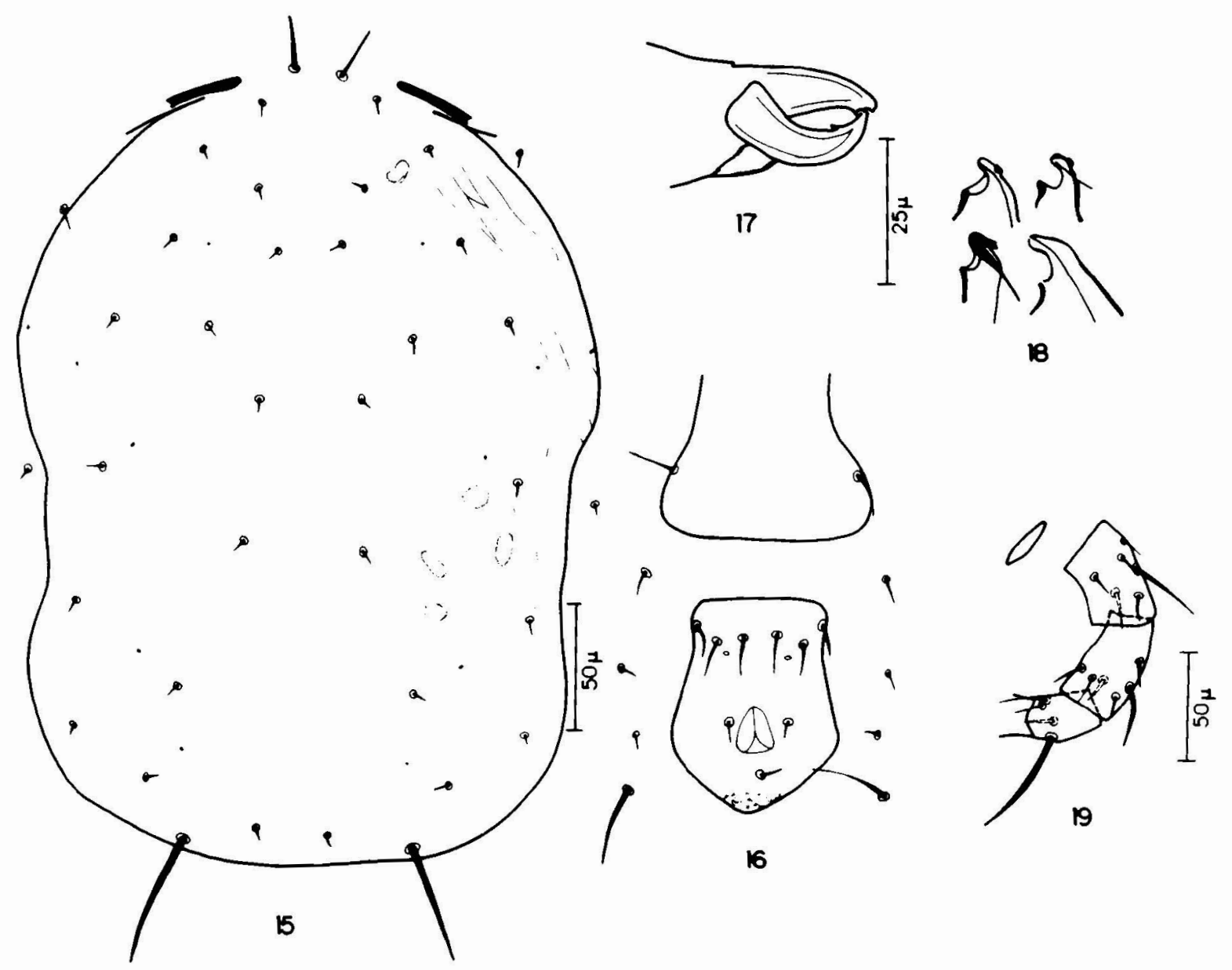

Figs. 15-19. Euseius minutisetus n. sp.. FEMALE: 15. dorsal shield; 16. ventral surface; 17. chelicera; 18. spermatheca; 19. genu, tibia and basitarsus of leg IV.

The measurements of a single adult male collected are: dorsal shield length 259 , width $180, \mathrm{j} 1$ and $\mathrm{j} 329, \mathrm{j} 4$ and j5 12, j6 and $\mathrm{J} 217, \mathrm{~J} 5 \mathrm{5}, \mathrm{22} 26, \mathrm{z} 431, \mathrm{z} 512, \mathrm{Z} 1 \mathrm{17}, \mathrm{Z4}$ 19, Z5 48, s4 41, S2 and S4 26, S5 31, r3 17, R1 12, SgeI and SgeII 24 , SgeIII 29, StiIII 22, SgeIV 38, StiIV 29, StIV 46 , ST1-ST3 60 , ST2-ST2 62, length of ventrianal shield 103, width of ventrianal shield at anterior corners 154 . Macrosetae of legs I and II setaceous; macrosetae of other legs knobbed.

\section{Euseius fustis (Pritchard \& Baker)} 1962: 283.

Amblyseius (Amblyseius) fustis Pritchard \& Baker,

Euseius fustis, Matthysse \& Denmark, 1981: 348; Moraes \& McMurtry, 1988: 15.

SPECIMENS EXAMINED: Yala, $30 \mathrm{~km}$ from Kisumu, I-1985, G.J.Moraes \& J.A. McMurtry; Nyatoto, Lambwe Valley, IX-1986, G.J. Moraes.
PREVIOUS RECORDS: Kenya, Nigeria and Zaire.

Euseius hima (Pritchard \& Baker)

(Fig. 14)

Amblyseius (Amblyseius) hima Pritchard \& Baker, 1962: 257; Blommers, 1976: 89.

SPECIMENS EXAMINED: Astrida, Rwanda, cherimoya, 22-V- 1955, E.W. Baker (holotype); Nkubu, Meru, Triumfetta rhomboidea, X-1985; Machakos/Katumani, weeds, IX-1988, J.S. Yaninek.

PREVIOUS RECORDS: India, Madagascar and Rwanda.

REMARKS: This species fits the description of the genus Euseius as given by McMurtry (1983), except for the position of the preanal setae (not on a transverse line, but with JV1 close to anterior margin of ventrianal 
shield). The specimens collected agree well with our measurements of the holotype. The average measurements of 4 females collected, the corresponding ranges (in parentheses) and the measurements of the female holotype are: dorsal shield length 271 (259-281) 275, width 171 (168-173) 173, j1 23 (22-26) 22, j3 24 (22-26) 26, j4 18 (17-19) 18, j5 16 (14- 18) 18, j6 17 (17) 19, J2 18 (17-19) 19, J5 7 (7-8) 6, z2 25 (24- 27) 26, z4 28 (26-30) 27, z5 16 (14-17) 19, Z1 18 (17-20) 22, Z4 21 (19-22) 24, Z5 46 (43-48) 45, s4 32 (31-34) 30, S2 22 (22-24) 24, S4 22 (22-23) 22, S5 22 (22-24) 22, r3 23 (22-24) 24, R1 14 (12-15) 16, Sge IV 25 (24-27) (not seen in holotype), StilV 24 (24-26) (not seen in holotype), StIV 43 (41-48) 34, ST1-ST3 54 (53-57) 53, ST2-ST2 58 (58-60) 60, G-G 51 (48-52) 52, ventrianal shield length 88 (84-91) 86, width at ZV2 level $43(41-45) 42$, width at anus level 51 (50-54) ca. 45, cervix of spermatheca $24(20-26) 24$, fixed digit 22 (22) (not measured), movable digit 21 (19-22) (not measured). The cervix of the spermatheca of the holotype, shown in figure 14, has an inflated proximal portion (18 long) and a constrict distal portion (6 long). In the specimens collected, there is no abrupt transition from an inflated to a constrict condition; instead, the cervix turns progressively narrower from the proximal to the distal portion.

Van der Merwe (1965) described Euseius natalensis (Van der Merwe) based on specimens collected from South Africa. We have not seen the types of this species, but from the original description, it seems that $E$. natalensis differs from $E$. hima basically by having somewhat longer $z 4$ (38) and s4 (42) and by having spermatheca similar to what was mentioned in the previously paragraph for specimens collected in this study. Swirski \& Ragusa reported E. natalensis from Nairobi- and Thika- Kenya, but made no comments as to setal lengths or shape of spermatheca. Blommers (1976) reported $E$. hima from Madagascar (intermediate latitude to Kenya and South Africa) and gave measurements and drawings of the specimens collected. His measurements are intermediate to the types of $E$. hima and E. natalensis, but the spermatheca is similar to the latter's and the specimens collected in this study. Considering the similar lengths of the cervix of both species and that possibly there is an intraspecific variation, it appears that $E$. natalensis is a junior synonym of $E$. hima, which could be confirmed by further collections around the type localities of both species.

\section{Euseius kenyae (Swirski \& Ragusa)}

Amblyseius kenyae Swirski \& Ragusa, 1978: 398. SPECIMEN EXAMINED: Nairobi, unknown tree, II-1985, G.J. Moraes \& J.A. McMurtry. PREVIOUS RECORDS: Kenya.
Euseius lokele (Pritchard \& Baker)

\begin{abstract}
Amblyseius (Amblyseius) lokele Pritchard \&
Baker, 1962: 271.

Amblyseius lokele, Swirski \& Ragusa, 1978: 405.

SPECIMENS EXAMINED: Stanleyville (now

Kisangani), Zaire, Manihot esculenta, 19-IV-1955, E.W.

Baker (holotype); Kilifi, Asystasia gangetica, X-1984;

Embu, X-1985; Nairobi, Leguminosae, I-1985, G.J.

Moraes \& J.A. McMurtry.
\end{abstract}

PREVIOUS RECORDS: Kenya and Zaire.

REMARKS: All specimens collected are larger than the holotype, and thus have dorsal shield setae generally longer. The smallest specimen and the closest to the holotype was collected in Kilifi, on the coast of Kenya. The average measurements of 5 females collected, the corresponding ranges (in parentheses) and the measurements of the holotype are: dorsal shield length 346 (334-355) 320, width 233 (228-240) 220, j1 29 (26-31) 33, j3 17 (10-22) 8, j4 9 (7-12) 8, j5 10 (7-12) 8, j6 11 (10-12) 8, J2 12 (10-12) 9, J5 7 (5-10) 6, z2 12 (10-14) 9, z4 13 (10-17) 8, z5 10 (7-12) 8, Z1 11 (10-12) 10, Z4 12 (10-14) 8, Z5 57 (53-58) 47, s4 21 (14-26) 13, S2 13 (1214) 11, S4 and S5 12 (10-14) 11, r3 15 (12-17) 16, R1 12 (12) not measured in holotype, SgeI 25 (22-29) 19, SgeII 32 (29-36) 28, SgeIII 37 (36-41) 33, StiIII 32 (31-34) 24, SgeIV 66 (60-74) 58, StiIV 42 (41-43) 39, StIV 76 (67-82) 66, ST1-ST3 61 (55-62) 53, ST2-ST2 72 (65-77) 66, G-G 78 (77-79) 65, ventrianal shield length 91 (86-96) 88, width at level of ZV2 48 (48-50) 44, width at level of anus $70(65-72) 65$, cervix of spermatheca 18 (17-22) 16 , fixed digit of chelicera 29 (29) not measured in holotype, movable digit of chelicera 26 (26) not measured in holotype. Peritreme extending forward to level of $j 1$ in the holotype and up to $\mathrm{j} 1$ or $\mathrm{j} 3$ in the specimens from Kenya. The major differences between the specimens collected and the holotype refer to setae $j 3$ and s4: although longer in the former specimens, they are close to the measurements of a paratype from Lwiro-Zaire (17 and 20, respectively) given by Swirski \& Ragusa (1978). A single specimen reported by those authors from Nairobi had relatively short $\mathrm{j} 1$ (23) and long $\mathrm{j} 3$ and $\mathrm{s} 4$ (22 and 28 , respectively).

\section{Euseius magucii (Meyer \& Rodrigues)} 223.

Amblyseius magucii Meyer \& Rodrigues, 1966:

SPECIMENS EXAMINED: Kisumu (by Lake Victoria), unidentified hairy-leaved herbs, I-1985, J.A. McMurtry \& G.J. Moraes.

REVIOUS RECORDS: Mozambique.

REMARKS: The specimens collected have shorter j3, z4 and SgeIV (31-34, 43 and 29-38) than the 
type material (43-49, 50-58 and 40-46, respectively). This was expected because the specimens collected are smaller (269-278) than the type specimens (284-311). As in $E$. hima, the ventrianal shield of this species is not typical for the genus, with preanal setae not on a transverse line, but with JV1 close to anterior margin of ventrianal shield.

Euseius minutisetus Moraes \& McMurtry, n. sp.

(Figs. 15-19)

DIAGNOSIS - This species differs from Euseius baetae (Meyer \& Rodrigues) and Euseius lokele (Pritchard \& Baker) by the shorter macrosetae and cervix of spermatheca. It differs from Euseius aizawai (Ehara \& Bhandhufalck), Euseius ovalis (Evans) and Euseius noumeae (Schicha) by having a wider cervix of the spermatheca.

FEMALE - (Figs. 15-19) (8 specimens measured).

Dorsum - Dorsal shield 322 (312-336) long and 222 (197-240) wide, with a few striae by the margins. Setae j1 11 (7-17), j3 11 (7-17), j4 6 (5-10), j5 6 (5-7), j6 7 (510), J2 8 (7-10), J5 5 (5-7), z2 9 (5-12), z4 8 (5-14), z5 7 (5-10), Z1 and Z4 8 (5-10), Z5 47 (43-50), s4 12 (7-22), S2, S4 and S5 8 (5-12), r311 (5-17), R1 7(5-10). All setae smooth.

Peritreme - Extending forward to level of $\mathrm{j} 3$ in the specimens with shorter dorsal shield setae, and to the level of $j 1$ in others.

Venter - Distance between ST1-ST3 55 (53-55), ST2-ST2 65 (62-72) and G-G 77 (70-82). Ventrianal shield vase-shaped, with 3 pairs of preanal setae and a pair of pores postero-laterad to JV2, 94 (91-101) long, 56 (53-60) wide at ZV2 level and 73 (65-77) wide at anus level.

Chelicera - Movable and fixed digits 25 (24-26) long each, with 1 and 2 teeth, respectively.

Spermatheca - Cervix as shown in figure 18, 10 (1012) long.

Legs - Macrosetae present on legs III and IV, blunt in specimens with shorter setae and knobbed in others: SgellI 18 (14-22), SgeIV 35 (29-41), StilV 24 (19-26), StIV 50 (48-53). Chaetotaxy of GeII 2, 2/0, 2/0, 1; GeIII $1,2 / 1,2 / 1,1$.

MALE - Unknown.

LOCALITY AND TYPE MATERIAL Holotype female and 5 paratype females, $150 \mathrm{~km}$ south of Nairobi, Mombasa Highway, Acacia sp., 6-II-1985, J.A. McMurtry; 1 paratype female, $40 \mathrm{~km}$ east of Kisumu, Acacia sp., 1-II-1985, J.A. McMurtry and G.J. Moraes.

\section{Euseius neofustis Moraes \& McMurtry}

Euseius neofustis Moraes \& McMurtry, 1988: 16.
SPECIMENS EXAMINED: Msambaweni, IX1984; Matuga, X- 1985.

PREVIOUS RECORDS: Kenya.

$$
\text { Euseius papayana (Van der Merwe) }
$$

Amblyseius papayana Van der Merwe, 1965: 57. SPECIMENS EXAMINED : Machakos/Katumani, Manihot esculenta, weeds, VIII-, IX- and X-1985, V-, VI-, VII-, VIII- and IX-1988, C.W. Kariuki, D.D. Mutiso, J.S. Yaninek, H. van den Berg; Machakos/Maruba, VIII-1988, D.D. Mutiso. Africa.

PREVIOUS RECORDS: Mozambique and South

REMARKS: This species is distinct in the genus Euseius by lacking seta $\mathrm{Z1}$.

\section{Genus Iphiseius Berlese}

Iphiseius Berlese, 1916: 33 (nomen nudum); Berlese, 1921: 95; Evans, 1954: 517; Van der Merwe, 1968: 104.

\section{Iphiseius degenerans (Berlese)}

Seius degenerans Berlese, 1889: 9.

Iphiseius degenerans, Berlese, 1921: 95; Evans, 1954: 518; McMurtry, 1977: 24.

Iphiseius (Iphiseius) degenerans, Van der Merwe, 1968: 105.

SPECIMENS EXAMINED: Machakos/Katumani, VII-1985, VIII- 1985, IX-1988, J.S. Yaninek, H. van den Berrg; Machakos/Maruba, VIII- and IX-1988, D.D. Mutiso; Nakuru, Ricinus communis, I-1985, G.J. Moraes \& J.A. McMurtry; East Kilaguni, Tsavo National Park, Citrus sp., II-1985, J.A. McMurtry; Rusinga Island, unknown tree, IX-1986, G.J. Moraes.

PREVIOUS RECORDS: Algeria, Egypt, Greece, Israel, Italy, Kenya, Lebanon, Madeira Island, Madagascar, Portugal, Rwanda, South Africa, Tanzania, Turkey, USSR and Zaire.

\section{Genus Kampimodromus Nesbitt}

Kampimodromus Nesbitt, 1951: 52.

Amblyseius (Kampimodromus), Pritchard \& Baker, 1962: 294; Van der Merwe, 1968: 160.

Kampimodromus spinosus (Meyer \& Rodrigues) 224.

Amblyseius spinosus Meyer \& Rodrigues, 1966:

SPECIMEN EXAMINED: Nairobi, Lycopersicon esculentum, I-1985, G.J. Moraes \& J.A. McMurtry. PREVIOUS RECORDS: Mozambique. 
Genus Paraphytoseius Swirski \& Shechter

Paraphytoseius Swirski \& Shechter, 1961: 113.

Paraphytoseius multidentatus Swirski \& Shechter

Paraphytoseius multidentatus Swirski \& Shechter, 1961: 113; Blommers, 1976: 87; McMurtry \& Moraes, 1984: 27.

Amblyseius (Paraphytoseius) multidentatus, Ehara \& Lee, 1971: 69; Ehara \& Bhandhufalck, 1977: 79.

Amblyseius (Ptenoseius) horrifer Pritchard \& Baker, 1962: 295 (synonymy, according to Matthysse \& Denmark, 1981).

Amblyseius (Paraphytoseius) horrifer, Van der Merwe, 1968: 169.

SPECIMENS EXAMINED: Msabaha, Waltheria indica, Vernonia aemulans, IX-1985; Siaya, unknown host, IX-1985; Matuga, W. indica, V. aemulans, Triumfetta rhomboidea, X-1985; Margarini, unknown host, X1985.

PREVIOUS RECORDS: Brazil, China, Hong Kong, India, Madagascar, New Caledonia, Nigeria, Pakistan and Thailand; Madagascar, Mozambique, South Africa and Zaire (as P. horrifer).

\section{Genus Phytoseius Ribaga}

Phytoseius Ribaga, 1902: 177; Denmark, 1966: 6.

\section{Phytoseius amba Pritchard \& Baker}

Phytoseius (Pennaseius) amba Pritchard \& Baker, 1962: 224

Phytoseius (Phytoseius) amba, Denmark, 1966: 46.

Typhlodromus (Phytoseius) amba, Van der Merwe, 1968: 101.

SPECIMENS EXAMINED: Beni, Zaire, Tithonia speciosa, 7- V-1955, E.W. Baker (holotype); Katumani, Solanum nigrum, weeds, IX-1985, IX-1988, J.S. Yaninek, H. van den Berg; Alupe, Busia, Triumfetta sp., Leonotis sp., Pseudathria hookeri, Compositae, Tephrosia nana, IX-1985; Embu, Physalis peruviana, Hibiscus sp., Neotonia wightii, X-1985; Nkubu, Meru, Triumfetta rhomboidea, X-1985; Siaya, Tephrosia sp., Solanum nigrum, X-1985; Saiwa, Ocimum lamiifolium, IX-1986; Maseno, $30 \mathrm{~km}$ northwest of Kisumu, Compositae, I1985, G.J. Moraes \& J.A. McMurtry; Rusinga Island, Solanum incanum, IX-1986, G.J. Moraes; Kamata, unknown host, IX-1986, G.J. Moraes.

PREVIOUS RECORDS: Kenya, Madagascar, Mozambique, Nigeria, Rwanda, South Africa and Zaire.

REMARKS: Most of the specimens collected have longer j3, z3, SgeIV, fixed and movable digits of chelicera, and cervix of spermatheca when compared to the holotype. The average measurements and respective ranges of 8 females collected (in parentheses), followed by our measurements of the female holotype are: dorsal shield length 288 (271-312) 283, width 144 (139-149) 165 , j1 24 (22-26) 24, j3 50 (41-60) 42, j4 4 (2-5) 3, j5 4 (2-5) 3, j6 5 (2-7) 4, J2 5 (5) 6, J5 11 (10-12) 11, z2 7 (5-10) 5, z3 24 (19-29) 17, z4 8 (5-12) 5, z5 5 (2-5) 5, Z4 62 (55-67) 64, Z5 75 (67-82) 83, s4 76 (70-86) 81, s6 78 (67-86) 79, r3 39 (34-43) 41, R1 14 (12-17) 12, SgeIV 26 (24-34) 21, StiIV 33 (29-38) 31, StIV 33 (26-43) 39, ST1-ST3 59 (5360) 60, ST2-ST2 70 (67-72) 79, G-G 69 (67-72) 63, ventrianal shield length 99 (84-108) 100 , width at ZV2 level 60 (55-67) 53, width at anus level 49 (48-53) 46, cervix of spermatheca $20(17-24) 12$, fixed digit 20 (17-24) 17, movable digit 24 (24) 17. The specimens from Saiwa are the closest to the holotype.

\section{Phytoseius hongkongensis Swirski \& Shechter}

Phytoseius (Phytoseius) hongkongensis Swirski \& Shechter, 1961: 99; Denmark, 1966: 44.

Phytoseius (Pennaseius) hongkongensis, Ehara \& Lee, 1971: 70; Blommers, 1976: 85.

Phytoseius hongkongensis, Schicha, 1984: 126.

SPECIMENS EXAMINED: Msabaha, Tephrosia villosa, Waltheria indica, IX-1985; Margarini, Melhania velutina, IX-1985; Arabuko/Sokoke, W. indica, X-1985; Matuga, $W$. indica, X-1985.

PREVIOUS RECORDS: Australia (Schicha, 1984), Hong Kong, Japan, Madagascar, Papua New Guinea, Taiwan and Thailand.

Phytoseius kisumuensis Moraes \& McMurtry, n. sp.

(Figs. 20-23)

DIAGNOSIS - This species differs from Phytoseius bulgariensis Wainstein by having shorter setae s4, s6, Z4, Z5, and cervix of spermatheca. It also differs from Phytoseius subtilis Wu \& Li and Phytoseius taianensis Liang \& Ke by having seta $\mathrm{J} 2$.

FEMALE - (Figs. 20-23) (2 specimens measured).

Dorsum - Dorsal shield smooth, 276 long and 132 wide. Setae j1 23 (22-24), j3 54 (53-55), j4 9(7-10), j5 10, j6 11 (10- 12), J2 11 (10-12), J5 7, z2 12, z3 30 (29-31), z4 23 (22- 24), z5 10, Z4 41, Z5 48, s4 60, s6 67, r3 41, R1 15 (12-17). Setae j1, j3, s4, s6, Z4, Z5 and r3 barbed; other setae smooth.

Peritreme - Extending forward to level of $\mathrm{j} 1$.

Venter - Sternal shield with 3 pairs of setae. Distances between sternal setae ST1-ST3 60 (58-62), ST2ST2 65, and genital setae G-G 62. Ventrianal shield with a few transverse striae, 106 long, 60 wide at ZV2 level 

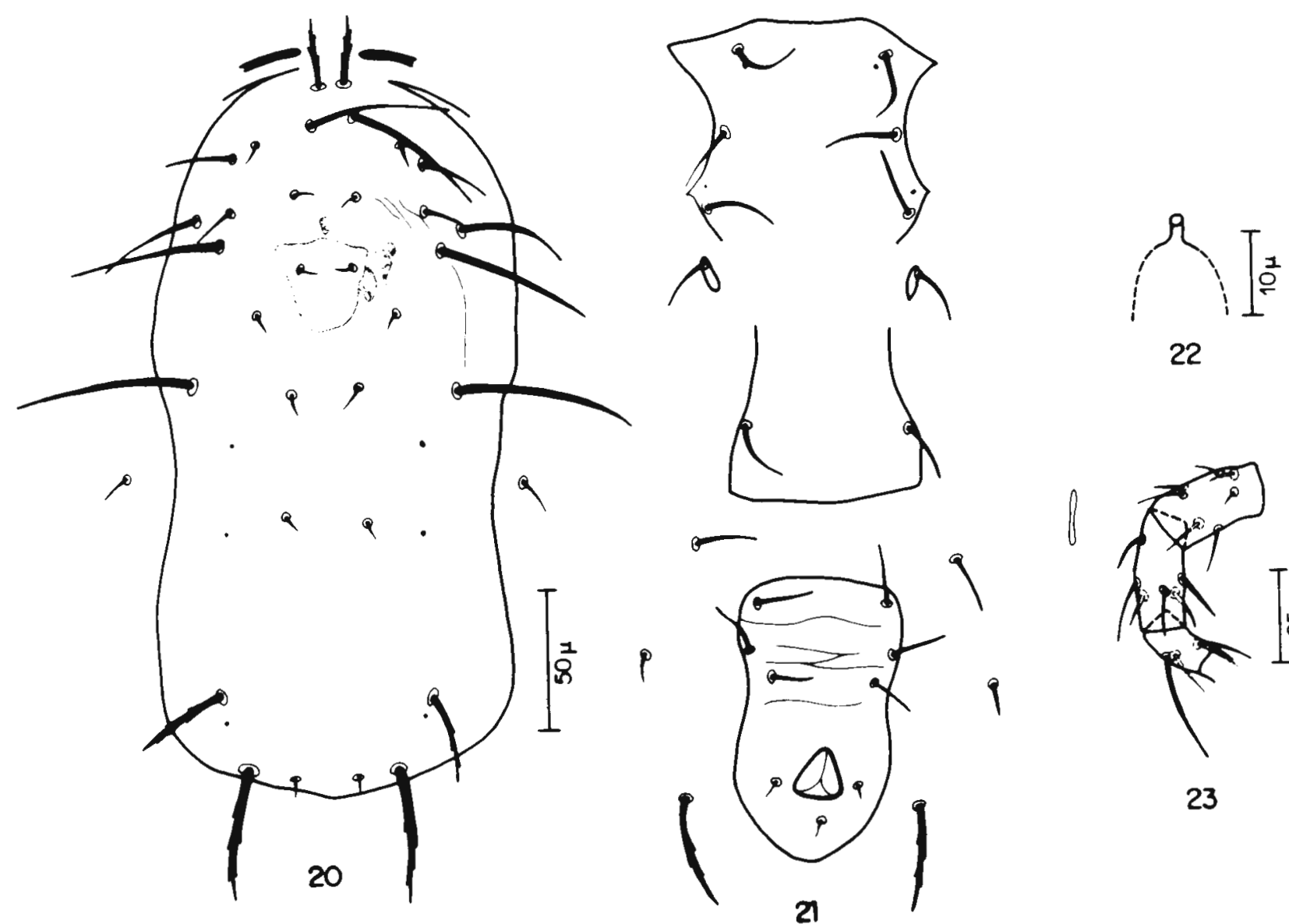

Figs. 20-23. Phytoseius kisumuensis n. sp.. FEMALE: 20. dorsal shield; 21. ventral surface; 22. spermatheca; 23. genu, tibia and basitarsus of leg IV.

and 53 wide at anus level; with 3 pairs of preanal setae and no pores.

Chelicera - Not possible to observe. ca. 5 long.

Spermatheca - With a cup-shapped distal portion,

Legs - With setiform macrosetae only on leg IV: Sge 22, Sti 24, St 29-34.

MALE - Unknown.

LOCALITY AND TYPE MATERIAL-Holotype female and 1 paratype female, Kisumu, by Lake Victoria, on hairy-leaved unidentified herbs, 30-I-1985, G.J. Moraes \& J.A. McMurtry.

Phytoseius neohongkongensis Moraes \& McMurtry, $\mathbf{n}$. sp.

(Figs. 24-31)

DIAGNOSIS - This species differs from Phytoseius hongkongensis Swirski \& Shechter by having shorter $\mathrm{z} 3$ and longer Z5 setae, and shorter cervix of spermatheca. It also differs from Phytoseius amba Pritchard \& Baker by having generally longer dorsal shield setae and shorter cervix of spermatheca.

FEMALE - (Figs. 24-28) (2 specimens measured).

Dorsum - Dorsal shield smooth, 270 (252-288)

long, 149 (146-151) wide, with a large pore posterior to 25. Setae j1 29 (26-31), j3 62, j4, j5 and j6 5, J2 6 (5-7), J5 5, z2 9 (8-10), z3 28 (26-29), z4 7, z5 5, Z4 80 (77-84), Z5 97 (91-103), s4 114 (108-120), s6 88 (82-94), r3 46, R1 11 (10-12). Setae j1, j3, z3, Z4, Z5, s4, s6 and $\mathrm{r} 3$ barbed.

Peritreme - Extending forward to level of $j 1$.

Venter - Sternal shield very lightly sclerotized. Distances between ST1-ST3 61 (60-62), ST2-ST2 66 (65-67) and G-G 66 (65-67). Ventrianal shield vase-shaped, with 3 pairs of preanal setae and no visible pores, 95 (94-96) long, 56 (55-58) wide at ZV2 level and 52 (50-53) wide at anus level.

Chelicera - Movable digit 28 (26-29) long, with 1 tooth; fixed digit 24 long, with 3 teeth.

Spermatheca - Cervix cup-shaped, 4-5 long, with a very short constriction close to the minute atrium. 


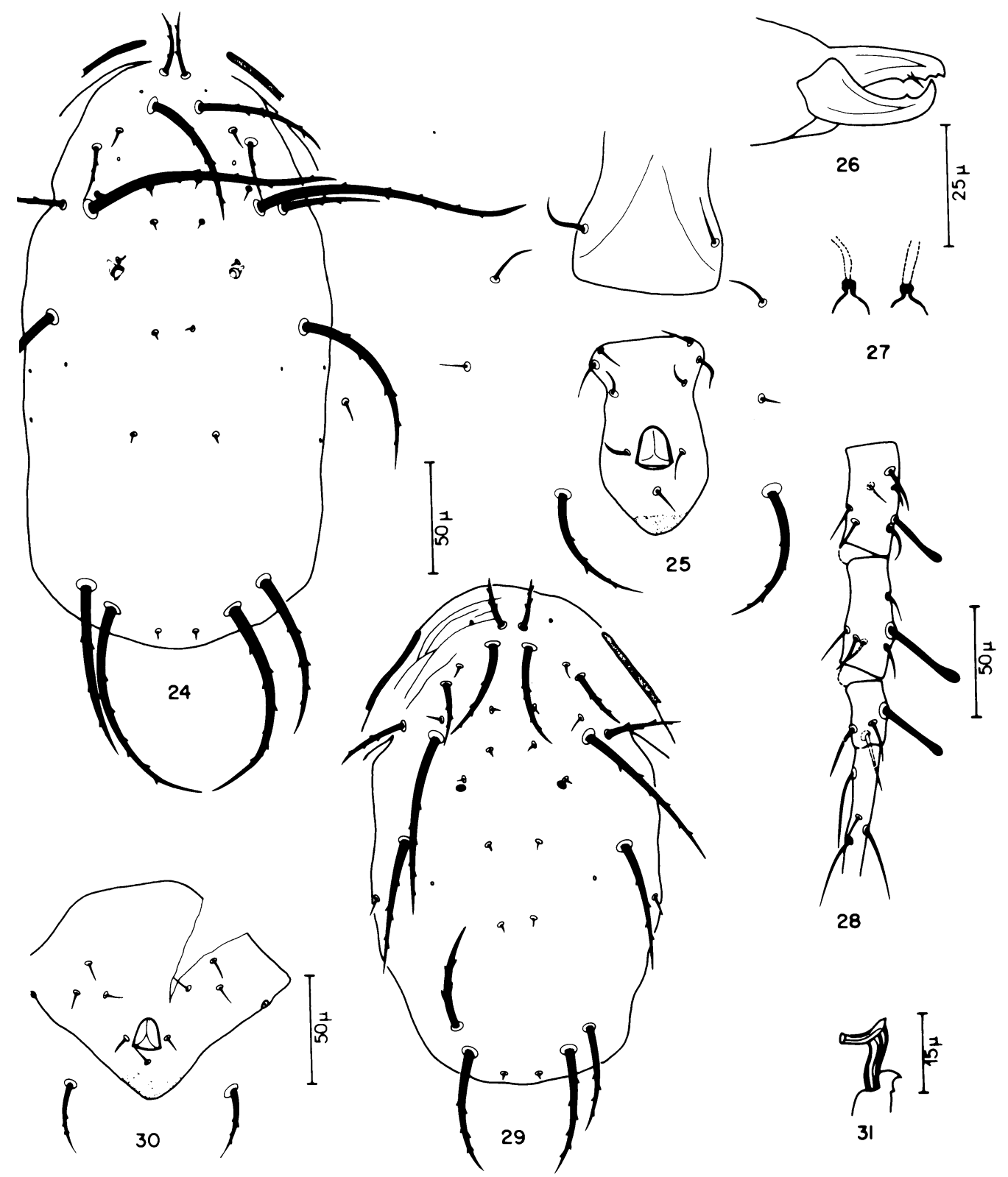

Figs. 24-31. Phytoseius neohongkongensis $\mathbf{n}$. sp.. FEMALE: 24. dorsal shield; 25. ventral surface; 26. chelicera; 27. spermatheca; 28. genu, tibia and basitarsus of leg IV. MALE: 29. dorsal shield; 30. ventrianal shield; 31. spermatodactyl.

Legs - With spatulate macrosetae only on leg IV: Sge 32 (31-34), Sti 38, St 35 (34-36). Chaetotaxy of GeII 2, 2/0, 2/0, 1; GeIII 1, 2/0, 2/0, 1 .

MALE - (Figs. 29-31) (2 specimens measured).

Dorsum - Dorsal shield smooth, 228 (223-234) long and 135 (134-137) wide, with a large pore posterior to z5. Setae j1 21 (19-22), j3 52 (50-53), j4 and j5 2, j6 3 (25), J2 5, J5 2, z2 10, z3 29, z4 9 (7-10), z5 4 (2-5), Z4 53 (50-55), Z5 50, s4 85 (84-86), s6 62, r3 38, R1 9 (7-10).
Setae j1, j3, z3, Z4, Z5, s4, s6 and r3 barbed.

Peritreme - Extending forward to level of $\mathrm{z} 2$.

Venter - Ventrianal shield with anterior margin considerably convex, with 3 pairs of preanal setae; 99 (96-103) long and 120 wide at anterior corners.

Spermatodactyl - Shaft 13 long.

Legs - With spatulate macrosetae only on leg IV: Sge 23 (22-24), Sti 24 (22-26), St 26.

LOCALITY AND TYPE MATERIAL - 

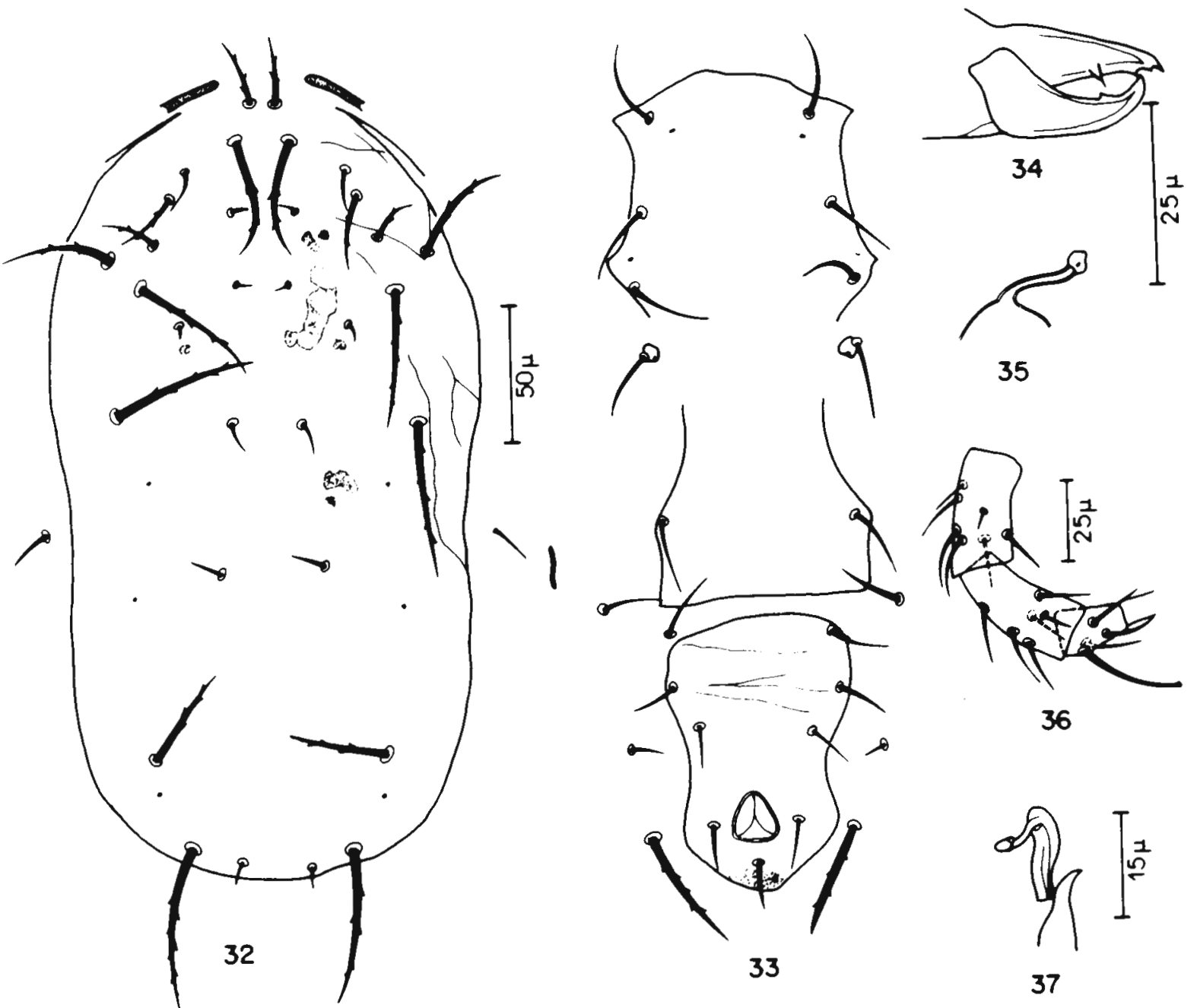

35

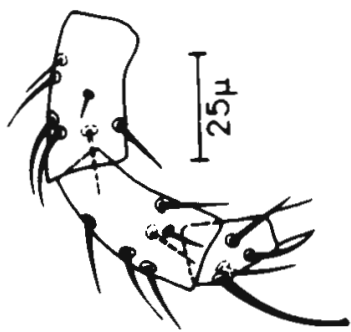

36

Figs.32-37. Phytoseius neomontanus n. sp.. FEMALE: 32. dorsal shield; 33. ventral surface; 34. chelicera; 35. spermatheca; 36. genu, tibia and basitarsus of leg IV. MALE: 37 . Spermatodactyl.

Holotype female, allotype male and 1 paratype male, Matuga, Solanum nigrum, 17-X-1985, H. van den Berg; 1 paratype female, Margarini, Melhania velutina, 11-IX1985, H. van den Berg.

Phytoseius neomontanus Moraes \& McMurtry, n. sp.

(Figs. 32-37)

DIAGNOSIS- This species is similar to Phytoseius montanus DeLeon, but the spermatheca is not trumpetshaped, j4 is ca. twice as long and StIV is ca. $40 \%$ shorter than in P. montanus.

FEMALE - (Figs. 32-36) (3 specimens measured).

Dorsum - Dorsal shield with a few striae on the margins, 286 (276-300) long and 144 (134-154) wide. Setae j1 23 (22-24), j3 41, j4 and j5 7, j6 11 (10-12), J2 13
(12-14), J5 10, z2 13 (10-17), z3 26 (24-29), z4 22 (19-24), z5 7, Z4 36, Z5 58 (55-60), s4 48 (46-50), s6 54 (53-55), r336 (36-38), R1 14 (12- 17). Setae j4, j5, j6, J2, J5, z2, z5 and R1 smooth; all others barbed.

Peritreme - Extending forward to level of $j 1$.

Venter - Sternal shield with posterior margin not clearly distinguishable; with 3 pairs of setae. Distances between ST1-ST3 58 (58-62), ST2-ST2 65 (62-67), G-G 65 (62-67). Ventrianal shield 82 long, $63(60-65)$ wide at level of ZV2 and 60 wide at level of anus; with 3 pairs of preanal setae and no pores.

Chelicera - Fixed and movable digits 24 and 26 long, respectively.

Spermatheca - Cervix with a cup-shaped distal portion (5long) and a cylindrical proximal portion (12 long).

Legs - Distinguishable macroseta only on tarsus IV, 34 (31-36) long with a small knob at tip. Chaetotaxy 
of GeII 2, 2/0, 2/0, 1; GeIII 1, 2/0, 2/0, 1.

MALE - (Fig. 37) (1 specimen measured).

Dorsum - Dorsal shield 240 long, with a few striae by the margins. Setae j1 22, j3 62, j4 and j5 7, j6 10, J2 12, J5 10, z2 8, z3 26, z4 19, z5 5, Z4 26, Z5 36, s4 and s6 41, r3 34, R1 7. Setae j4, j5, j6, J2, J5, z2, z5 and R1 smooth; all others barbed.

Legs - Distinguishable macroseta only on tarsus IV, 31 long.

Spermatodactyl - Shaft 14 long.

LOCALITY AND TYPE MATERIAL Holotype female, allotype male and 2 paratypes from Kericho, on hairy-leaved Malvaceae, 30- I-1985, G.J. Moraes \& J.A. McMurtry.

Phytoseius intermedius Evans \& MacFarlane

Phytoseius (Dubininellus) intermedius Evans \& MacFarlane, 1961: 587; Denmark, 1966: 70.

Phytoseius (Phytoseius) intermedius, Ehara, 1972: 170.

Phytoseius (Dubininellus) yira Pritchard \& Baker, 1962: 227 (synonymy according to Denmark, 1966).

SPECIMENS EXAMINED: Nairobi, unidentified Leguminosae, I-1985, J.A. McMurtry \& G.J. Moraes.

PREVIOUS RECORDS: India, Japan, Madagascar, Pakistan and Zimbabwe; Zaire (as $P$. yira).

Genus Typhlodromus Scheuten 368.

Typhlodromus Scheuten, 1857: 111; Chant, 1965:

\section{Typhlodromus magdalenae Pritchard \& Baker}

Typhlodromus (Typhlodromus) magdalenae Pritchard \& Baker, 1962: 218; Van der Merwe, 1968: 65; Chant \& Yoshida Shaul, 1987: 1774.

SPECIMENS EXAMINED: Rusinga Island, unknown tree, IX-1986, G.J. Moraes.

PREVIOUS RECORDS: Kenya, Rwanda, South Africa and Zaire.

\section{ACKNOWLEDGEMENT}

To H.A. Denmark, Florida Department of Agriculture and Consumer Affairs, Gainesville, Florida, for loan of type specimens; to G. Oloo, International Centre of Insect Physiology and Ecology, for the assistance in collection of specimens around Mbita Point; to R. Markham, C.A.B. International, Kenya Station, for the encouragement and help in the collection of specimens and to the Africa-wide Biological Control Program/International Institute of Tropical Agriculture for partially sponsoring this work.

\section{REFERENCES}

Beglyarov, G.A. 1962 . On the fauna of the predaceous mites of the family Phytoseiidae in Krasnodar Region. In: Biologicheskiy Metod Bor'by s Vreditelyami i Boleznyami Cel'skhozyaystvennykh kul'tur. Vynusk 1, pp. 198-203.

Berlese, A. 1889 . Acari, Myriapoda et Scorpiones hucusque in Italia reperta.Tipografia del Seminario, Padova, v. VI,Fasc. 54, No. 7, 8, 9.

Berlese, A. 1914 . Acari nuovi. Redia, 10: 113-150.

Berlese, A. (1916). Centuria prima di Acari nuovi. Redia, 12: 19- 66.

Berlese, A. 1921 . Acari, Myriapoda et Pseudoscorpiones hucusque in Italia reperta. I. Indice sinonimico dei generi e delle specie illustrate nei fascicoli 1 a 101. Redia, 14(1/2): 77- 105.

Blommers, L. 1974 . Species of the genus Amblyseius Berlese, 1914, from Tamatave, East Madagascar (Acarina: Phytoseiidae). Bull. Zool Mus. Univ. Amsterdam, 3: 143-155.

Blommers, L. 1976. Some Phytoseiidae (Acarina: Mesostigmata) from Madagascar, with descriptions of eight new species and notes on their biology. Bijdragen tot Dierkunde, 46(1): 80-106

Chant, D.A. 1959 . Phytoseiid mites (Acarina: Phytoseiidae). Part I. Bionomics of seven species in southeastern England. Part II. A taxonomic review of the family Phytoseiidae, with descriptions of thirty-eight new species. Can. Entomol., Supplement 12, $166 \mathrm{pp}$.

Chant, D.A. 1965 . Generic concepts in the family Phytoseiidae (Acarina: Mesostigmata). Can. Entomol., 97: 351-374.

Chant, D.A. and R.I.C. Hansell. 1971 . The genus Amblyseius (Acarina: Phytoseiidae) in Canada and Alaska. Can. J. Zool., 49(5): 703-758.

Chant, D.A.. R.I.C. Hansell, H.J. Rowell and E. Yoshida Shaul 1978 . A study of the family Phytoseiidae (Acarina: Mesostigmata) using the methods of numerical taxonomy. Can. J. Zool., 56: 1330-1347.

Chant, D.A. and E. Yoshida Shaul, 1986 . A new subfamily, Cydnodromellinae, in the family Phytoseiidae (Acari: Gamasida). Can. J. Zool., 64: 2811-2823.

Chant, D.A. and E. Yoshida Shaul. 1987 . A world review of the pyri species group in the genus Typhlodromus Scheuten (Acari: Phytoseiidae). Can. J. Zool., 65: 1770-1804.

Daneshvar, H. and H.A. Denmark. 1982. Phytoseiids of Iran (Acarina: Phytoseiidae). Internat. J. Acarol., 8: 3-14.

DeLeon, D. 1966 . Phytoseiidae of British Guyana with keys to species (Acarina: Mesostigmata). In: 
Studies on the fauna of Suriname and other Guyanas, 8: 81-102.

Denmark, H.A. 1966 . Revision of the genus Phytoseius Ribaga, 1904 (Acarina: Phytoseiidae). Fla. Dept. Agr. Bull., 6: 1-105.

Ehara, S. 1972. Some phytoseiid mites from Japan, with descriptions of thirteen new species (Acarina: Mesotigmata). Mushi, 46(12): 137-173.

Ehara, S. and A. Bhandhufalck. 1977 . Phytoseiid mites of Thailand (Acarina: Mesotigmata). J. Fac. Educ. Tottoni Univ., Nat. Sci., 27(2): 43-82.

Ehara, S. and L.H.Y. Lee 1971 . Mites associated with plants in Hong Kong. J. Fac. Educ. Tottori Univ., Nat. Sci., 22(2): 61- 78.

Evans, G.O. 1954. The genus Iphiseius Berl. (Acarina: Laelaptidae). Proc. Zool. Soc. London, 124: 517526.

Evans, G.O. and D. Macfarlane. 1961 . A new mites of the genus Phytoseius Ribaga (Acari: Mesostigmata). Ann. Magaz. Nat. Hist., Ser. 13, 4: 587-588.

Livshitz, I.Z. and N.N. Kuznetsow. 1972. Phytoseiid mites from Crimea (Parasitiformes: Phytoseiidae). p. 13-64. In: Pests and diseases of fruit and ornamental plants. The All-Union V. I. Lenin Acad. Agric. Sci., The State Nikita Botanical Gardens, Proc., 61: 1-144. Yalta.

Matthysse, J.G. and H.A. Denmark. 1981 . Some phytoseiids of Nigeria (Acarina: Mesostigmata). Fla. Entomol., 64: 340-357.

McMurtry, J.A. 1977 . Some predaceous mites (Phytoseiidae) on citrus in the Mediterranean region. Entomophaga, 22: 19-30.

McMurtry, J.A. 1983 Phytoseiid mites from Guatemala, with descriptions of two new species and redefinitions of the genera Euseius, Typhloseiopsis, and the Typhlodromus occidentalis species group (Acari: Mesostigmata). Int. J. Entomol., 25: 249-272.

McMurtry, J.A. and G.J. de Moraes, 1984. Some phytoseiid mites from the South Pacific, with descriptions of new species and a definition of the Amblyseius largoensis species group. Int. J. Acarol., 10: 27-37.

Meyer, M.K.P. and M.C. Rodrigues, 1966. Acari associated with cotton in southern Africa (with reference to other plants). Garcia de Orta,Revista Junta Investigacoes de Ultramar, 13(2): 195226.

Moraes, G.J. de \& J.A. McMurtry. 1988. Some phytoseiid mites from Kenya, with description of three new species. Acarologia, 29(1): 13-18.

Moraes, G.J. de, J. A. McMurtry and H. A. Denmark. 1986. A catalog of the mite family Phytoseiidae. References to taxonomy, synonymy, distribution and habitat. EMBRAPA-DDT, Brasilia, 353 p.
Moutia, L.A. 1958 Contribution to the study of some phytophagous Acarina and their predators in Mauritius. Bull. Entomol. Res., 49: 59-75.

Muma, M.H. 1967 . New Phytoseiidae (Acarina: Mesostigmata) from southern Asia. Fla. Entomol., 50: 267-280.

Muma, M.H., H.A. Denmark and D. DeLeon . 1970 . Phtyoseiidae of Florida. Anthropods of Florida and neighboring land areas, 6: $150 \mathrm{pp}$.

Nesbitt, H.H.J. 1951 . A taxonomic study of the Phytoseiidae (Family Laelaptidae) predaceous upon Tetranychidae of economic importance. Zool. Verhandel., 13, $64 \mathrm{p}+32$ plates.

Pritchard, A.E. and E.W. Baker, 1962. Mites of the family Phytoseiidae from Central Africa, with remarks on genera of the world. Hilgardia, 33: 205-309.

Ribaga, C. 1902. Gamasidi planticoli. Riv. Patol. Veg., 10: 175-178.

Rowell, H.J., D.A. Chant and R.I.C. Hansell . 1978 . The determination of setal homologies and setal patterns on the dorsal shield in the family Phytoseiidae (Acarina: Mesostigmata). Can. Entomol., 110: 859-876.

Scheuten, A. 1857. Einiges uber Milben. Arch. Naturgesch., 23: 104-112.

Schicha, E. 1981. Five known and five new species of phytoseiid mites from Australia and the South Pacific. Gen. Appl. Ent., 13: 29-46.

Schicha, E. 1983. New species, new records, and redescriptions of phytoseiid mites from Australia, Tahiti,and the African region (Acari: Phytoseiidae). Int. J. Entomol., 25(2-3): 103- 126.

Schicha, E. 1984. Contribution to the knowledge of the genus Phytoseius Ribaga in Australia, the South Pacific and Indian Ocean region, with four new species and records of known species (Acarina: Phytoseiidae). Internat. J. Acarol., 10: 117-128.

Swirski, E. and S. Ragusa , 1978 . Three new species of phytoseiid mites from Kenya (Mesostigmata: Phytoseiidae). Zool. J. Linnean Soc., 63: 397-409.

Swirski, E. and R. Shechter. 1961. Some phytoseiid mites (Acarina: Phytoseiidae) of Hong-Kong, with a description of a new genus and seven new species. Israel J. Agric. Res., 11: 97-117.

Van der Merwe, G.G. 1965. South African Phytoseiidae (Acarina). I. Nine new species of the genus Amblyseius Berlese. J. Entomol. Soc. S. Africa, 28: 57-76.

Van der Merwe, G.G. 1968 . A taxonomic study of the family Phytoseiidae (Acari) in South Africa with contributions to the biology of two species. So. Africa Dept. Agr. Tech. Services,Entomol. Mem., 18: 1-198. 
Wainstein, B.A. 1961. New species of mites of the genus Typhlodromus (Parasitiformes: Phytoseiidae) in Georgia. Trudy Instituta Zoologii Akademii Nauk Gruzinskoy SSR, 18: 153-162.

Wainstein, B.A. 1962a. Some new predatory mites of the family Phytoseiidae (Parasitiformes) of the USSR fauna. Entom. Obozr., 41: 230-240; Emtomol. Rev., 41: 139-146.

Wainstein, B.A. 1962b . Revision du genre Typhlodromus Scheuten, 1857 et systematique de la famille des Phytoseiidae (Berlese, 1916) (Acarina: Parasitiformes). Acarologia, 4: 5-30.

Wainstein, B.A. 1975 . Predatory mites of the family
Phytoseiidae (Parasitiformes) of Yaroslavl Province. Entom. Rev., 54(4): 138-143; Entom. Obozr., 54(4): 914-922.

Wainstein, B.A. and G.I. Shcherbak . 1972 . Gamasid species of the genus Amblyseius Berlese, 1914 (Parasitiformes: Phytoseiidae) new for the Ukrainian fauna. Vestn. Zool., 6(6): 35-44.

Yaninek, J.S. and H.R. Herren .1988. Introduction and spread of the cassava green mite, Mononychellus tanajoa (Bondar) (Acari: Tetranychidae), an exotic pest in Africa and the search for appropriate control methods: a review. Bull. Entomol. Res., 78: 1-13. 